\title{
TPAHCПOPT
}

UDC 656.7

DOI https://doi.org/10.32838/2663-5941/2021.2-2/23

Akmaldinova V.Ye.

orcid.org/0000-0002-7087-2088

National Aviation University

Volkovska G.G.

orcid.org/0000-00019674-3770

National Aviation University

\section{AIRCRAFT FLEET OPERATION EFFICIENCY: COMPARATIVE ANALYSIS}

The article is devoted to the problems of aircraft fleet functioning in the present economic situation, the issues of strategic air traffic management based on modern information technologies and intelligent services using advanced achievements in analysing, forecasting optimization, aviation modeling for operational information processing and decision making in the field under analysis. Air transport development longterm and current planning, being a multifaceted problem, includes the task of forecasting the demand for transport services, routing passenger flows, formation of airlines network and the optimal distribution of aircraft routes. Rationalization of passenger services plays an important role in improving the organization of airlines operation, meeting the demand of the population for air transportation, development of international relations and integration of the state economy into the world economic system. It is determined that in order to increase the efficiency of aircraft fleet planning, management and operation it is necessary to analyze information concerning alternative ways of air transportation development in view of the complexity of formalized assessment of further growth prospects of air transportation depending on many different factors of political, economic, technical, organizational, social and environmental nature. Investigation of air transport performance indicators allows to identify the main problematic issues of the development and prospects for the air passenger transport market in Ukraine. The key factors for formation of an effective route network and a system of internal air transportation have been determined: regular (non-charter flights); higher frequency of flights for network development at the expense of economically active population; the quality of aircraft fleet with the capacity corresponding to the volume of demand for air transportation; affordable fares for passengers by subsidizing airline revenues.

Key words: air carrier, aircraft model, aircraft fleet, route network, optimization, demand, domestic air transportation, operation efficiency, airline strategy.

Introduction. The necessity of effective solutions while meeting the flight safety requirements makes the task of reforming the civil aviation and creating the legal field of its operation in accordance with advanced technologies constantly relevant.

The way to solve this problem in medium terms could be the maintaining of the air transport competitiveness by optimizing costs, upgrading the aircraft fleet with most economical aircraft. Given the lack of competitive Ukrainian-made technique for flights on international routes foreign models of long-haul and medium-haul aircraft are currently used. In this regard, the national industry can be supported by supplying machines for domestic airlines.
Therefore, defining the strategy for the domestic passenger air transport market development through the aircraft fleet optimal use is one of the main tasks. Its solution will lead to the development of the aviation industry and creation of a Flag Air Carrier, as Ukraine is considered to be an aviation state with developed infrastructure.

Solving the problem of fleet management by reducing its operating costs as an economic lever of profit growth will increase the airline efficiency and achieve a certain profitability level, helping the carrier to survive in difficult economic crisis. In this regard, to solve the problem of improving the aircraft fleet efficiency in regular domestic passenger traffic it is extremely important [1]. 
The existing domestic airlines route network reflects the situational model of socio-economic development of Ukraine and Kyiv as the main economic center.

At the same time, many economists note that the further development of the country requires increasing the role of regions in the economy and creation of new centers of active growth. To solve this problem it is necessary to increase the mobility of the population and the formation of sustainable interregional transport links. The current model of transportation hinders not only the civil aviation development, but the economy of many regions as well.

The recent reduction in the number of domestic airlines has led to the destruction of the single economic space within the country, which has led to:

- the destruction of the system of intra- and interregional economic ties;

- slowing down the growth rate of gross regional product of state entities;

- difficult financial situation of regional airlines and airports having not enough workload in conditions of low effective demand for transportation.

Thus, the creation of a single transport space within Ukraine and its constituent regions, given the important role of air transport, requires the formation of effective domestic air traffic route network models, development and implementation of efficient state support mechanisms.

In international practice, there exists a state support for regional aviation in almost every economically developed or developing country.

The most typical example of the best international practice from the countries of North, Central and South America is the implementation of regional flights subsidizing program in the United States. The countries of the European Union, each individually and within the single economic space of the Union, have a rich history of air transportation state regulation.

The experience of domestic air transportation state regulation is of great interest due to the fact that in order to make a single decision as to the state regulation within the European Union, common principles and approaches, a lot of preliminary work is carried out to study and agree the views of many participants, with practices and interests of all EU member states taken into account.

Literature review. In the international practice of economically developed countries, there are mechanisms of competition state regulation, aimed at creating favorable conditions for the development of regional air carriers. States regulate market access for new players with low demand on a particular airline to avoid negative consequences for existing airlines and to prevent unjustified "destructive" competition. It is advisable to regulate the access of new players to an air route when the demand for air transportation along a particular air route is sufficient to load the flights of one air carrier to perform economically viable flights [2].

Regulation of air carriers access to low-loaded air routes is economically justified not only in terms of subsidizing air transportation, but also with a low airline profitability level, if this ensures stability and regularity of air transportation, reduces the risk of airline closure due to so-called "destructive competition" with a new airline entering the route. An important aspect in unprofitable regional destinations is to maintain the necessary level of costs to provide aircraft airworthiness, staff training and other aspects of ensuring flight safety. Competitive pressure with unjustified destructive competition is forcing regional airlines to reduce flight safety costs. Practice shows that in the first place there are savings on the maintenance and personnel training costs which directly affects flight safety. Thus, taking into account the advanced world experience, the issues of a reasonable approach to market regulation in order to avoid "destructive" competition on many regional routes should be taken into account by the aviation authorities when implementing the route network of domestic flights [3].

Problem statement. To form variants of the route network models for domestic air transportation, it is reasonable to apply the following algorithm:

1. Formation of databases on the demand for air transportation by means of specialized software packages and the demand forecast within the region.

2. Analysing alternate modes of transport on routes and forecasting possible redistribution of passenger flows between the transport modes.

3 . Analysing the demand and forecasting domestic air transportation.

4. Formation of a route network project for internal air transportations.

5. Analysing and forecasting air transportation tariffs taking into account alternative transport modes.

6 . Forecasting revenues, costs and profitability of routes, taking into account alternative modes of transport in the region.

7. Assessment of the need for subsidizing domestic air routes.

It is necessary to solve a number of additional problems with interested state and local authorities, to determine the institutional scheme of the project implementation, possibilities of budget funding at the 
expense of budget funds of different levels, to find out preliminary interest in the project of air carriers and other tasks.

Taking into account the world experience, the main criteria for selecting new domestic air routes should be the following:

1) the route length - not less than $300 \mathrm{~km}$;

2) average percentage of aircraft payload - at the level of $75 \%$;

3) average monthly flight operation peroid 150 hours per an aircraft.

An important task in the formation of projects for creation and development of regional air carriers is to define the optimal types of aircraft for the primary route promotion stage and secondary stages when the routes reach the planned load values each year of the project [4].

Materials and methods. The need in aircraft for air transportation is calculated on the basis of the domestic air transportation route network model variants formed, including economically justified proposals for the route list, flight frequencies and aircraft classes.

Current domestic airlines require, as a rule, a larger capacity aircraft each subsequent year. This must also be taken into account in the projects.

In general, the algorithm tested for practical application by airlines, large leasing companies, aircraft manufacturers should contain the following blocks:

1) formation of appropriate databases on the demand for air transportation and transportation by alternative modes of transport;

2) distribution of air traffic volumes in the desired regions (or to other segments in case the segmentation is not geographical) in terms of flight areas;

3) determination of the parameters influencing air transportation growth rates on the basis of macroeconomic indicators of the analyzed regions and forecasting the growth rates;

4) some substages of econometric analysis and airlines operation economic modeling;

5) defining the conditions of redistribution of passenger flow growth by flights and passenger capacity intervals;

6) distribution of flows by the estimated passenger capacity intervals;

7) calculation of the required number of aircraft by the specified economic indicators [5].

In order to successfully implement projects, to achieve a quality result, it is necessary to analyze the demand for air transportation and other modes of transport, forecast and optimize the aircraft fleet in the Ukraine regions, in the short, medium and long term.
Before launching the projects, it is also necessary to analyze the airport infrastructure for the possibility of servicing the proposed route network of domestic air transportation in terms of the technical and operational condition of airports and landing sites. In complex projects mechanisms of financing their development are developed.

An important aspect in the implementation of regional air transport development projects is to maintain an optimal level of airport charges and the cost of ground servicing.

About $35 \%$ of the domestic air transportation cost is the cost of airport fees and tariffs for aircraft ground maintenance, passengers, mail and cargo handling. If the airport is included into the state regulated list or regulation is transferred to the regional level, the airport fee must be agreed with the regulator. In this case, the maximum discounts may be $60 \%$ of the amount of airport charges. As for ground handling services, due to the fact that they are not regulated, there is a much greater opportunity to provide discounts. It is necessary to take into account best practices and recommendations on the most rational approaches to reducing the airport services cost in terms of regulated and unregulated services.

The long-awaited reduction in the airport services cost is due to the simplified certification requirements for regional and local airports with low flight intensity.

It should be borne in mind that cost reduction does not always lead to lower costs for the consumer. To solve this problem it is recommended to use the state ownership of airports and landing pads of infrastructure, as regional aviation, with existing economic realities and solvent public demand, remains socially significant but unattractive business that requires the government support [6].

The planning and achievement of the airline's competitiveness is based on the solution of such specific intra-industry tasks as planning and optimization of the route network and aircraft fleet, which should be solved in close cooperation with each other.

However, given the restrictions on the airline budget to optimize the aircraft fleet, the priority is the problem of the route network optimizing, which requires analysing and forecasting the air transportation market. The airline production and economic performance indicators: the number of flights and landings, flight hours and kilometers, aircraft layout, exhibited capacity, seat-kilometers offered, passenger flows and passenger turnover (passenger $/ \mathrm{km}$ ), income and expense rates calculated by the technical feasibility of their provision and route network is the basis for preparing the airline budget for future periods. 
The solution of the problem of route network optimization includes a systemic analysis of many air transportation market indicators, such as:

1) structure, condition and possibilities of own aircraft fleet optimization;

2) planned costs for keeping representative offices;

3) all types of operating costs;

4) the size of markets in the directions of flights;

5) opportunities to capture the share of these markets;

6) the possibility of obtaining convenient slots for scheduling to ensure potential demand for transfer at hub airports, etc.

However, the main role in substantiating the flight feasibility is played by profitability indicators and its impact on the network effect as a whole. In addition to minimizing costs, the flight profitability is affected by the level of prices and commercial load, expressed in the seat occupancy rate for passenger air transport.

The methodological basis for solving the problems of forecasting demand and prices in the air transportation market is the availability of information systems monitoring market parameters.

To determine the optimal structure of the aircraft fleet, it is necessary to analyze a significant number of factors arising both in the field of aircraft production and in the field of operation affecting the formation of the aircraft fleet and its efficiency. It is also necessary to analyze the process of passenger traffic, taking into account the requirements for various parameters characterizing the aircraft tactical and technical capabilities. At the same time it is necessary to take into account external factors, such as climatic and geographical ones.

Comprehensive accounting of the aircraft operation factors allows to reduce the cost of fuel and energy resources, with downtime taken into account, and to choose the most optimal aircraft option to achieve this goal. This process is iterative, and it can be divided into two stages:

Stage 1. The optimization of the aircraft fleet is carried out taking into account the whole complex of a certain aircraft type maintenance, routes, degree of loading, production costs;

Stage 2. Based on the results of the preliminary study, the aircraft type is choosen and an optimal area of its use is determined according to economic criteria.

In operating aircraft and striving to reduce their cost, there is a need for maximum unification, i.e. to lower the number of aircraft options operated. Therefore, to make the right decision when choosing aircraft options for the formation of the fleet it is necessary to carefully compare both aircraft complex parameters and numerous requirements for the process of passenger traffic to achieve maximum effect at minimum cost [7].

When considering the choice of the optimal aircraft fleet, it is necessary to take a systemic approach to goal planning, determining the prospects for goal development, as well as finding a comprehensive solution to the problem using most relationships both within the air transport system and outside it. Thus, the system approach allows to solve three main hierarchical tasks:

1) achieving the maximum efficiency of the aircraft fleet in the process of passenger transportation;

2) solving the economic and mathematical problem of optimizing the passenger traffic performance;

3 ) determining the required number of each aircraft option for each route in order to form an optimal aircraft fleet [ibid].

The optimization processes described above form the planned production indicators for forecasting revenues from flights, namely: total sales revenues for airline flights; total sales revenue for Interline flights; total sales revenues on the territory of Ukraine; total income from sales abroad; expected revenues from sales for domestic flights; expected revenues from sales for international flights; total sales revenue through various channels; expected sales revenues at some points; the amount of the commission; planned expenses for the keeping the representative offices; efficiency of sales channels, agency network and individual agents.

Determining the planned production indicators allows to assess the physical feasibility of the chosen air transportation strategy by means of the aircraft fleet, transportation capacity and the airline economic potential, which ensure sticking to the schedule and the planned revenues [8].

Conclusions. Further development of the country requires increasing the role of regions in the economy and the creation of new centers of active growth. To solve this problem it is necessary to increase the population mobility and to form sustainable interregional transport links. The current transportation model hinders the development not only of civil aviation, but the economy of many regions as well.

The key factors for the formation of an efficient route network and domestic air transportation system are identified: regular (non-charter flights); high flight frequency for network development due to economically active population; aircraft fleet corresponding to the demand for air transportation; affordable fares for passengers (due to subsidizing revenues of operating airlines), the use of transfer schemes in the route 
network formation to reduce subsidies, ensuring the required safety level and a preset level of comfort for passengers.

The current instability in the Ukraine air market will affect the long-term airlines strategy in forming their aircraft fleet. Airlines are now focusing on pre- paring for further growth with minimal operational efficiency risks.

Narrow-body aircraft will continue to be the largest market segment. Demand for them will recover faster due to the fact that such aircraft are used on short-haul routes and in the domestic market.

\section{References:}

1. П Підсумки діяльності авіаційної галузі України. Розділ “Новини”. Київ, 2021. URL: http://avia.gov.ua/ (дата звернення: 10.03.2021)

2. Транспорт і зв'язок України: статист. збірник / Державний комітет статистики України. Київ, 2005. $263 \mathrm{c}$

3. Висоцька I.I. Стан та перспективи розвитку пасажирських авіаційних перевезень на внутрішніх лініях України. Економіка: проблеми теорії та практики: зб. наук. праць. Вип. 192, т. ІІ. Дніпропетровськ, 2004. C. 569-575.

4. Козлюк І.О. Моделювання процесів функціонування авіаційного транспорту з метою прогнозування показників його діяльності : дис. ... доктора техн. Наук : 05.13.06. Київ, 2007. 332 с.

5. Леонтьев Р.Г. Прогнозирование авиапотоков и оптимизация управления воздушной транспортной системой. Москва, 1984. 184 с.

6. Методичні рекомендації з формування собівартості перевезень (робіт, послуг) на транспорті, затверджені наказом Міністерства транспорту України від 05.02.2001 № 65. URL: http://zakon.nau.ua/doc/?uid=10 40.644.1\&nobreak=1\#st2. (дата звернення: 15.03.2021).

7. Висоцька I.I. Імітаційна модель функціонування підсистеми обслуговування пасажирів в аеропорту. Формування ринкових відносин в Україні: зб. наук. праць. За ред. І.К. Бондар. Київ, 2007. Вип. 5 (72). C. $79-83$.

8. Юн Г. Н. Задача эффективного базирования воздушных судов. Киев : КМУГА, 1998. Вип. 2. C. $109-113$.

\section{Акмалдінова В.Є., Волковська Г.Г. ЕФЕКТИВНІСТЬ ЕКСПЛУАТАЦІЇ ПОВІТРЯНИХ СУДЕН: ПОРВІНЯЛЬНИЙ АНАЛІЗ}

Стаття присвячена проблемам функиіонування парку повітряних суден в умовах економічної кризи, питанням стратегічного управління авіаційним транспортом на основі сучасних інформаційних технологій та інтелектуальних послуг з використанням передових досягнень в сфері аналізу, оптимізації, прогнозування, моделювання в авіаційній галузі для обробки оперативної інформації та прийняття рішень в сфері, щзо аналізується. Перспективне і поточне планування розвитку авіатранспорту, як багатогранна проблема, включає завдання щодо прогнозування попиту на транспортні послуги, маршрутизації пасажирських потоків, формування мережі авіаліній та оптимального розподілу маршрутів руху повітряних суден. Рачіоналізачія пасажирських сполучень відіграє важсливу роль в удосконаленні організації роботи авіапідприємтв, у задоволенні попиту населення на авіаперевезення, розвитку міжнародних зв'язків та інтеграції економіки держави до світової економічної системи. Визначено, що для підвищення ефективності планування, управління та експлуатації парку повітряних суден необхідно проаналізувати інформацію щодо альтернативних иляхів розвитку повітряного транспорту у зв'язку зі складністю формалізованої оцінки подальшоі перспективи зростання авіаційних перевезень, щзо залежить від багатьох різних чинників політичного, економічного, технічного, організаційного, сочіального $i$ екологічного характеру. Дослідження показників функиіонування повітряного транспорту дозволяють визначити основні проблемні питання та перспективи розвитку ринку авіачійних пасажсирських перевезень в Україні. Визначено ключові фактори формування ефективної маршрутної мережі та системи внутрішніх авіаційних перевезень: регулярні (не чартерні рейси); більш висока частота польотів для розвитку мережі за рахунок економічно активного населення; якість парку повітряних суден, що за місткістю відповідає обсягу попиту на авіаперевезення; доступні тарифи для пасажирів за рахунок субсидування доходів авіакомпаній.

Ключові слова: авіаперевізник, модель повітряного судна, парк повітряних суден, мережа авіаліній, оптимізація, попит, внутрішні авіаперевезення, ефективність експлуатації, стратегія авіакомпаній. 